\title{
A NEW SPECIES OF SOLAROPSIS BECK, 1837 (GASTROPODA: STYLOMMATOPHORA: SOLAROPSIDAE) FROM THE BRAZILIAN AMAZON
}

\author{
RODRIGO BRINCALEPE SALVADOR
}

\begin{abstract}
Natural History Department, Museum of New Zealand Te Papa Tongarewa, New Zealand (e-mail: salvador.rodrigo.b@gmail.com); @ https://orcid.org/0000-0002-4238-2276
\end{abstract}

\begin{abstract}
A specimen of Solaropsidae from the collection of the Academy of Natural Sciences of Drexel University (Philadelphia, USA) was recognised as a potential new species based on shell morphology. With support from a multi-locus molecular phylogenetic analysis, a new species is described here: Solaropsis penthesileae sp. nov. It is native to the Amazon Rainforest in Pará state, northern Brazil, and it is closely related to $S$. nimbus (Simone). It differs in its more discoid shell, with a wider body whorl that bears a stronger median angulation in its lower spire. The specimen was collected in 1998 and is an example of the long shelf-life invertebrates may have in museum collections before they are identified and formally described. It is also a reminder of the importance of those collections for biodiversity studies.
\end{abstract}

KEY WORDS: Amazon; land snails; Pará; Solaropsidae; Solaropsis penthesileae sp. nov., sundial snails

Publication LSID D7329285-9A14-4236-840F-26CB099FE715

\section{INTRODUCTION}

The discovery of new species mostly happens not in the field, but rather in museum collection stores (ALLMON 1994, KEMP 2015). The material collected during expeditions, surveys, or by chance, will often remain undisturbed in museum cabinets for decades, awaiting discovery. As such, museums are a source of potential new species (GREEN 1998). There is an average of 21 years of the so-called "shelf-life" separating the time when a specimen is first collected from the formal description and naming of a new species in a scientific publication (FONTAINE et al. 2012). However, the shelf-life can sometimes extend to over a century (SALVADOR \& CAVALLARI 2014, KEMP 2015).

Fortuitously, while conducting research on Neotropical Stylommatophora, I came across a unique specimen in the collection of the Academy of Natural Sciences of Drexel University (Philadelphia, USA) belonging to the family Solaropsidae, the sundial snails. The specimen was remarkably similar to Solaropsis nimbus (Simone, 2010), described from the northernmost region of the Brazilian Amazon Rainforest and of a very unique morphology within the Solaropsidae (SIMONE 2010, CALCUTT et al. 2020). Nevertheless, that specimen was immediately diagnosable from $S$. nimbus based on shell morphology, raising the possibility that it represented a still undescribed species. Herein, a combination of morphological characters and genetic data is used to support the description of a new species of the Solaropsidae. 


\section{MATERIAL AND METHODS}

The specimen studied here belongs to the collection of the Academy of Natural Sciences of Drexel University (Philadelphia, USA), registration number ANSP A473903. It was fixed in ethanol and preserved in ethanol $80 \%$. The snail was collected in the Floresta Nacional de Caxiuanã ("Caxiuanã National Forest"; see discussion below), which is a reserve in the lower Amazon. To my knowledge, no survey of the terrestrial mollusc fauna of this important forest reserve has been published to date.

A small fraction of tissue from the specimen's foot was clipped for DNA extraction using the QIAGEN DNEasy ${ }^{\circledR}$ Blood \& Tissue Kit (standard protocol). The choice of markers for sequencing was based on

Table 1. Species used in the present phylogenetic analysis, with GenBank registration numbers, locality data, and references to the original publications

\begin{tabular}{|c|c|c|c|c|c|}
\hline Species & $\mathrm{CO} 1$ & $16 \mathrm{~S}$ & $28 \mathrm{~S}$ & Provenance & References \\
\hline \multicolumn{6}{|l|}{ Discidae } \\
\hline $\begin{array}{l}\text { Discus rotundatus } \\
\text { (O.F. Müller, 1774) }\end{array}$ & FJ917285 & FJ917265 & FJ917240 & $\begin{array}{l}\text { Germany: Hesse, } \\
\text { Frankfurt am Main }\end{array}$ & DINAPOLI \& KLUSSMANN-KOLB 2010 \\
\hline \multicolumn{6}{|l|}{ Sagdidae } \\
\hline $\begin{array}{l}\text { Polydontes acutangula } \\
\text { (Burrow, 1815) }\end{array}$ & - & KF246985 & KF207686 & $\begin{array}{l}\text { Puerto Rico: Rio } \\
\text { Grande }\end{array}$ & ROSENBERG et al. unpublished \\
\hline $\begin{array}{l}\text { Platysuccinea portoricensis } \\
\text { (Shuttleworth, 1854) }\end{array}$ & - & KF247011 & KF207714 & Puerto Rico: Ponce & SEI et al. 2017 \\
\hline $\begin{array}{l}\text { Sagda cf. epistylioides } \\
\text { (Férussac, 1821) }\end{array}$ & - & KF247005 & KF207708 & $\begin{array}{l}\text { Jamaica: } \\
\text { Westmoreland } \\
\text { Parish }\end{array}$ & SEI et al. 2017 \\
\hline \multicolumn{6}{|l|}{ Solaropsidae } \\
\hline $\begin{array}{l}\text { Caracolus caracollus } \\
\text { (Linnaeus, 1758) }\end{array}$ & - & KF246970 & KF207671 & Puerto Rico: Jayuya & SEI et al. 2017 \\
\hline $\begin{array}{l}\text { Caracolus sagemon } \\
\text { (Beck, 1837) }\end{array}$ & - & KF246973 & KF207674 & Cuba: Holguin & SEI et al. 2017 \\
\hline $\begin{array}{l}\text { Solaropsis cf. gibboni } \\
\text { (L. Pfeiffer, 1846) }\end{array}$ & - & KF246988 & KF207688 & $\begin{array}{l}\text { Colombia: } \\
\text { Cundinamarca }\end{array}$ & SEI et al. 2017 \\
\hline $\begin{array}{l}\text { Solaropsis cf. juruana } \\
\text { (Ihering, 1905) }\end{array}$ & MT080614 & MT080821 & MT080838 & $\begin{array}{l}\text { Brazil: Pará, } \\
\text { Altamira, Usina de } \\
\text { Belo Monte }\end{array}$ & CALCUTT et al. 2020 \\
\hline $\begin{array}{l}\text { Solaropsis heliaca } \\
\text { (d'Orbigny,1835) }\end{array}$ & - & KF246989 & KF207689 & Bolivia: Santa Cruz & SEI et al. 2017 \\
\hline $\begin{array}{l}\text { Solaropsis juruana } \\
\text { (Ihering, 1905) }\end{array}$ & MT080616 & MT080813 & MT080840 & $\begin{array}{l}\text { Brazil: Acre, Rio } \\
\text { Branco, Bairro } \\
\text { Universitário }\end{array}$ & CALCUTT et al. 2020 \\
\hline $\begin{array}{l}\text { Solaropsis nimbus } \\
\text { (Simone, 2010) }\end{array}$ & MT080613 & MT080826 & MT080837 & $\begin{array}{l}\text { Brazil: Amazonas, } \\
\text { Pico da Neblina }\end{array}$ & CALCUTT et al. 2020 \\
\hline $\begin{array}{l}\text { Solaropsis penthesileae } \\
\text { sp. nov. }\end{array}$ & MZ313463 & - & MZ313211 & $\begin{array}{l}\text { Brazil: Pará, } \\
\text { Caxiuanã }\end{array}$ & Present work \\
\hline $\begin{array}{l}\text { Solaropsis punctata } \\
\text { (Wagner, 1827) }\end{array}$ & MT080619 & MT080824 & - & $\begin{array}{l}\text { Brazil: Bahia, } \\
\text { Parque Nacional } \\
\text { Monte Pascoal }\end{array}$ & CALCUTT et al. 2020 \\
\hline $\begin{array}{l}\text { Solaropsis rosaria } \\
\text { (Pfeiffer, 1850) }\end{array}$ & MT080617 & MT080825 & MT080841 & $\begin{array}{l}\text { Brazil: Goiás, } \\
\text { Parque Estadual da } \\
\text { Terra Ronca }\end{array}$ & CALCUTT et al. 2020 \\
\hline $\begin{array}{l}\text { Solaropsis rugifera } \\
\text { Dhorn, } 1882\end{array}$ & MT080618 & MT080822 & MT080842 & $\begin{array}{l}\text { Brazil: Roraima, } \\
\text { Porto Velho }\end{array}$ & CALCUTT et al. 2020 \\
\hline Solaropsis sp. 1 & - & KF246990 & KF207690 & Ecuador: El Zarza & SEI et al. 2017 \\
\hline Solaropsis sp. 2 & - & KF246991 & KF207691 & $\begin{array}{l}\text { Paraguay: } \\
\text { Concepción }\end{array}$ & SEI et al. 2017 \\
\hline \multicolumn{6}{|l|}{ Zachrysiidae } \\
\hline $\begin{array}{l}\text { Zachrysia havanensis } \\
\text { (Pilsbry, 1894) }\end{array}$ & - & KF246992 & KF207692 & $\begin{array}{l}\text { Puerto Rico: } \\
\text { Mayaguez }\end{array}$ & SEI et al. 2017 \\
\hline
\end{tabular}


the previous Solaropsidae phylogeny of CALCUTT et al. (2020): (1) the barcoding fragment of the mitochondrial COI gene (primers LCO/HCO; FOLMER et al. 1994); (2) the mitochondrial 16S rRNA gene (primers 16SarL and 16SbrH; SIMON et al. 1994); (3) the 5 ' end of the 28S rRNA gene (primers LSU-1/ LSU-3 and LSU-2/LSU-5; WADE \& MORDAN 2000, WADE et al. 2006). PCR settings were as follows: (1) COI: initial denaturation at $96^{\circ} \mathrm{C}(3 \mathrm{~min}) ; 35$ cycles of denaturation at $95{ }^{\circ} \mathrm{C}(30 \mathrm{~s})$, annealing at $48{ }^{\circ} \mathrm{C}$ ( $1 \mathrm{~min})$, and extension at $72{ }^{\circ} \mathrm{C}(2 \mathrm{~min})$; final extension at $72{ }^{\circ} \mathrm{C}$ (5 min); (2) 16S: same as COI, but $46{ }^{\circ} \mathrm{C}$ annealing temperature; (3) 28S: initial denaturation at $95{ }^{\circ} \mathrm{C}(3 \mathrm{~min}) ; 40$ cycles of denaturation at $95{ }^{\circ} \mathrm{C}(30 \mathrm{~s})$, annealing at either $50{ }^{\circ} \mathrm{C}$ (LSU-1/ LSU-3 fragment) or $45{ }^{\circ} \mathrm{C}$ (LSU-2/LSU-5 fragment) ( $1 \mathrm{~min})$, and (4) extension at $72{ }^{\circ} \mathrm{C}(5 \mathrm{~min}$ for LSU1/LSU-3 fragment or 2 min for LSU-2/LSU-5 fragment); final extension at $72{ }^{\circ} \mathrm{C}(4 \mathrm{~min})$. The PCR products were then quantified via agarose gel electrophoresis, followed by cleaning with ExoSAP-IT ${ }^{\mathrm{TM}}$ (Affymetrix Inc.), and sent out for Sanger sequencing. The sequences were assembled in Geneious Prime (v. 2020.2.2, Biomatters Ltd.), quality-proofed, and uploaded to NCBI GenBank.

Phylogenetic analysis was conducted to define the position of the specimen within the Solaropsidae,

\section{RESULTS}

The COI and 28S markers of the ANSP specimen were successfully sequenced (GenBank accession numbers MZ313211 and MZ313463, respectively), but the 16S marker could not be successfully amplified after several attempts and variations in the PCR protocol. The 28S fragment amplifies together with the ITS2 marker, which is present in the GenBank record though it was not used for the phylogenetic analysis.

After running the sequence alignment of each marker through Gblocks, 571 informative positions were retained for the COI marker (out of 638), 438 were retained for $16 \mathrm{~S}$ (out of ca. 528), and 423 were retained for 28S (out of 448).

The resulting Bayesian tree (Fig. 1) showed strong support for most of the solaropsid clades, de- using all available sequences of this family (Table 1) from the studies of SEI et al. (2017) and CALCUTT et al. (2020). Other taxa of the Sagdoidea and a taxon of the Discoidea were chosen as outgroups (Table 1). Alignment of sequences was conducted in Geneious Prime through the MUSCLE plugin (EDGAR 2004) with default settings (i.e. optimised for accuracy). The alignment of each marker was manually proofed for errors in Geneious and then run through Gblocks (TALAVERA \& CASTRESANA 2007; using the least restrictive settings) to eliminate poorly-aligned and divergent positions that could interfere with the phylogenetic analysis.

The phylogenetic analysis (Bayesian inference) was performed with the MrBayes (v.3.2.7: RONQUIST et al. 2012) plugin in Geneious. Two concurrent analyses were run, each with four Markov chains of 15 million generations (the first $20 \%$ discarded as 'burnin'), the default priors, nst $=6$, rates $=$ invgamma, temperature parameter $=0.1$, sampling every 1,000 generations; substitution model parameters were unlinked across the three markers. Markov chain Monte Carlo (MCMC) convergence was assessed by examining the standard deviation of split frequencies $(<0.01)$ and trace plots in Geneious.

spite the polytomy. The position of the Caracolinae and the family rank of the Zachrysiidae remains ambiguous, as already noted by CALCUTT et al. 2020. More importantly, the present ANSP specimen has perfect support (posterior probability $=1$ ) as the sister taxon of $S$. nimbus, as predicted by its morphology. Those two terminals are more genetically distant from one another than other well-supported crown Solaropsis (Fig. 1). In particular, the COI sequences of the ANSP specimen and that of S. nimbus have between $91.2 \%$ and $93.7 \%$ identity, depending on the reading of some ambiguous bases. These results support the suspicion that the ANSP specimen represents a new species. 


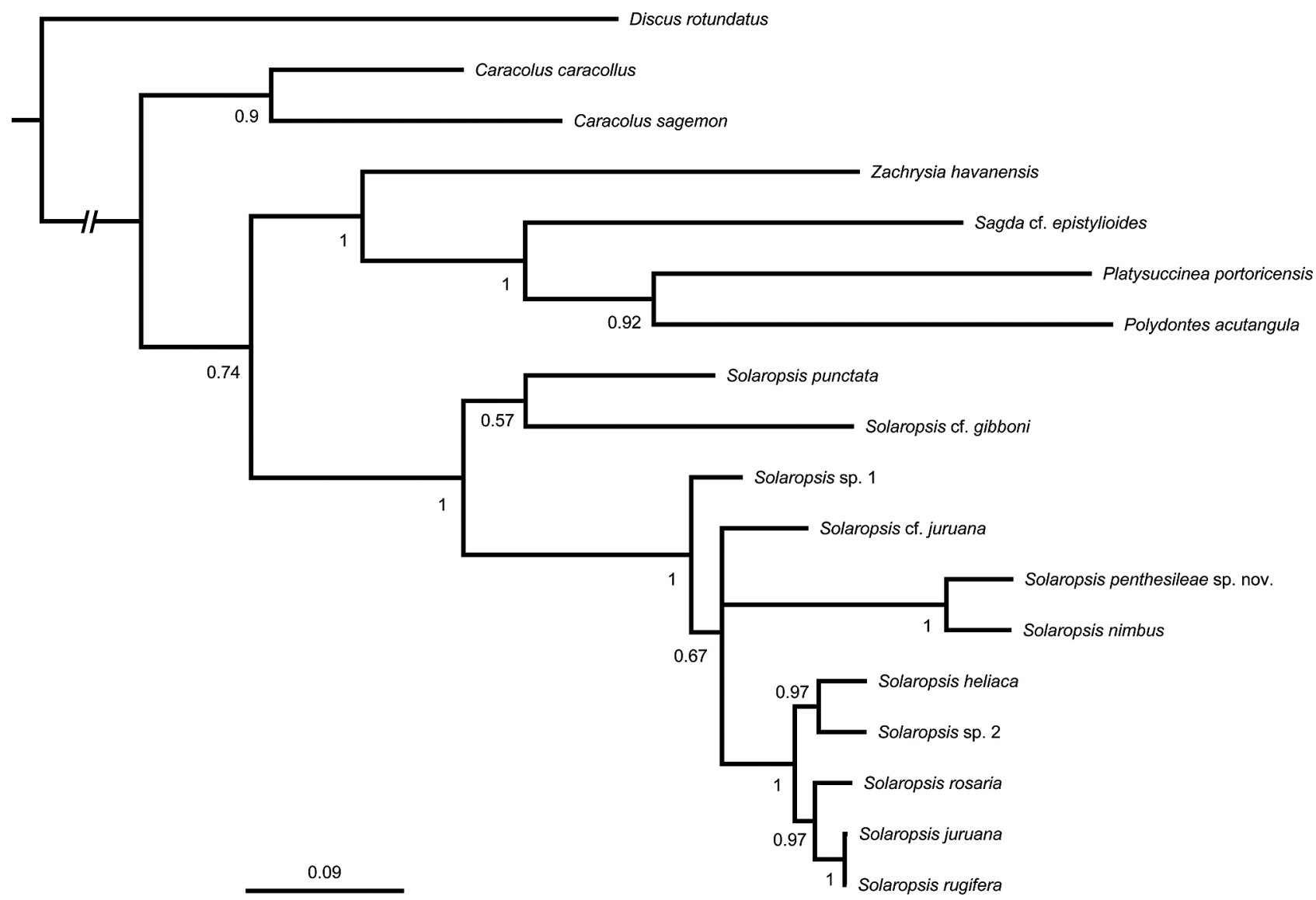

Fig. 1. Bayesian tree showing the position of Solaropsis penthesileae sp. nov. within the Solaropsidae. The nodes show posterior probabilities ( 0 to 1 ); the scale is substitutions per site

\section{SYSTEMATICS}

\section{Superfamily Sagdoidea Pilsbry, 1895}

Family Solaropsidae H. Nordsieck, 1986

Genus Solaropsis H. Beck, 1837

Type species: Helix pellisserpentis Gmelin, 1791, by subsequent designation; junior synonym of Solaropsis undata ([Lightfoot], 1786).

\section{Solaropsis penthesileae sp. nov.}

Figs 2-6

\section{LSID D4F10593-C526-4099-9486-B2C9C6630EA4}

Type locality. Brazil, Pará state, Caxiuanã, Fazenda. Holotype. ANSP A473903 (R. NEWMAN leg., 17/ VI/1998; ex Delaware Museum of Natural History collection).

Diagnosis. Shell small, globular to discoid, bearing a weak median angulation on body whorl and a faint sub-sutural shoulder. Colour pattern consisting of three brown dotted lines: one on the shoulder, one immediately above the median angulation, and one on the base of the whorl.
Description. Shell (Fig. 2) small, globular to discoid. Protoconch (Fig. 5) smooth, 1 1/2 whorl, of uniform light ochre colour; transition to teleoconch marked by faint callus and onset of colour pattern. Shell colour ochre, with patterns in darker shades of brown, consisting of square markings on shoulder (Fig. 3) and three spiral dotted lines (one on the shoulder, one immediately above the median angulation, and one on the base of the whorl). Periostracum almost uniformly covered by small hairs (Fig. 6), except for abapical area of shell. Teleoconch smooth, except for very faint growth lines, but hairs give it a dotted appearance. Suture shallow. Whorls uniformly increasing in height and width (Figs 2, 3). Body whorl wide, with a faint sub-sutural shoulder and a weak median angulation (Fig. 2). Precise morphology of aperture and umbilicus cannot be assessed, due to the specimen not having the typical adult reflected peristome (Fig. 4). Aperture apparently D-shaped, small, abapically positioned in relation to body whorl (Fig. 4). Measurements. Holotype: shell height $=10.8 \mathrm{~mm}$; shell width $=15.3 \mathrm{~mm}$. 
Sequence data. GenBank accession numbers MZ313463 (COI) and MZ313211 (ITS2+28S).

Distribution. Known only from the type locality, Caxiuanã, which refers to the Floresta Nacional de Caxiuanã ("Caxiuanã National Forest"), in Melgaço municipality. The term used for the precise locality was "Fazenda" [=farm], which potentially means the research station in the forest (Ferreira Penna Scientific

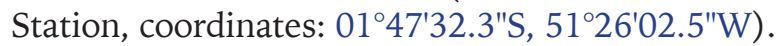

Habitat. The specimen was found on an açaí palm (Euterpe oleracea Mart.), but there is not enough information to assess whether it was in a forested area or an anthropically-disturbed one. In any event, the Caxiuanã Forest is part of the Amazon Rainforest biome and is notable by its 'terra firma' forests, which do not flood seasonally and make up around $85 \%$ of Caxiuanã's total area (LISBOA 1997). A smaller fraction (ca. 12\%) of the Caxiuanã includes floodplain forests as well (LISBOA 1997).

Etymology. The new species is named after Penthesilea, the Amazonian queen from Greek mythology. Suggested vernacular name: Penthesilea's sundial.

Remarks. Conchologically, $S$. penthesileae sp. nov. (Figs 2-6) is most similar to S. nimbus (Figs 7-8) from the neighbouring Amazonas state. This is also shown by their sister-taxon relationship in the phylogeny (Fig. 1) and the pairwise identity between their COI sequences. S. penthesileae sp. nov. can be diagnosed by its more discoid shell, with a wider body whorl that bears a stronger median angulation, and a lower spire. The adult shell of $S$. penthesileae sp. nov. would supposedly be wider, but only one specimen of the species and two specimens of $S$. nimbus are known (SIMONE 2010), precluding any meaningful comparison in that regard.

A further similar species is $S$. aff. rosaria (L. Pfeiffer, 1850), reported from Tocantins and Minas Gerais states (SALVADOR et al. 2015, 2021). However, S. penthesileae sp. nov. is much smaller, with a more delicate general appearance, a more prominently raised spire, stronger median angulation on the body whorl, and a smaller and more circular aperture, positioned more abapically in relation to body whorl. S. juruana Ihering, 1905, known from Acre state and western Amazonas state, has a similar colour pattern, but is slightly bigger and has a fully discoid shell. Both $S$. rosaria and $S$. juruana are placed within the crown group in the present phylogeny (Fig. 1).

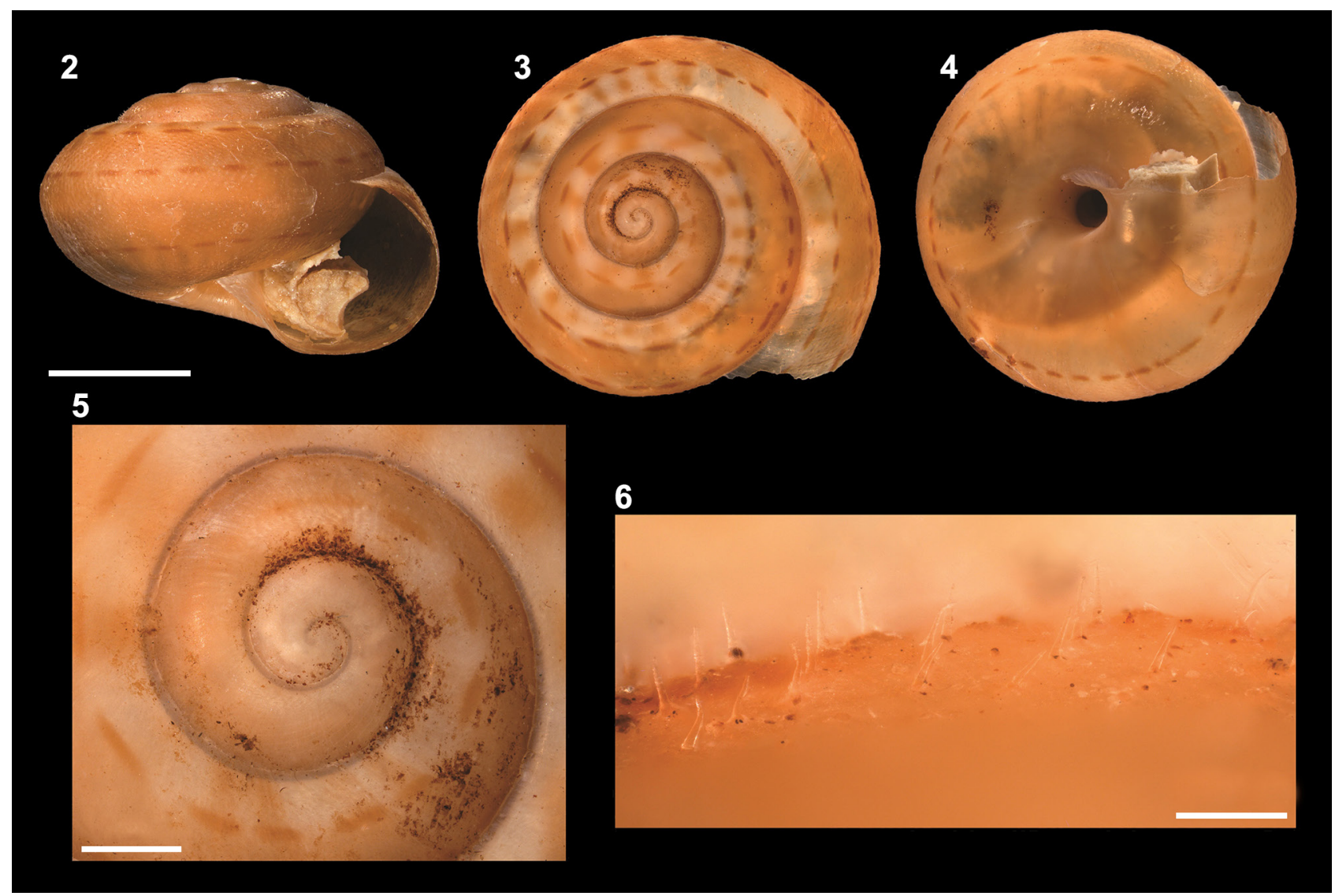

Figs 2-6. Solaropsis penthesileae sp. nov., holotype ANSP A473903 (shell height = $10.8 \mathrm{~mm}$; shell width = $15.3 \mathrm{~mm}$ ): 5 detail of protoconch; 6 - detail of teleoconch showing the hairs. Scale bars $5 \mathrm{~mm}(2-4,6)$ and $1 \mathrm{~mm}(5)$ 


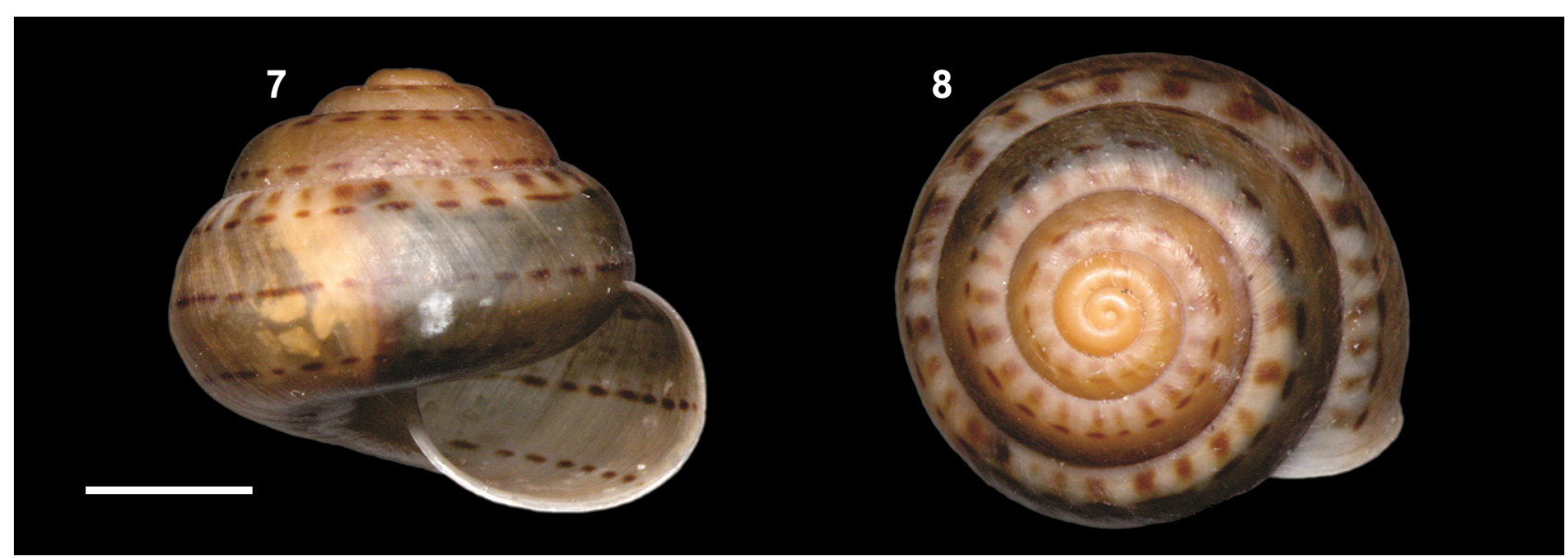

Figs 7-8. Solaropsis nimbus, holotype MZSP 87151 (shell height $=13.1 \mathrm{~mm}$, shell width $=15.7 \mathrm{~mm}$ ); images from BIRCKOLZ et al. (2016). Scale bar $5 \mathrm{~mm}$

\section{DISCUSSION}

S. penthesileae sp. nov. was found in a region of Brazil which has been malacologically neglected (SALVADOR 2019). Its closest relative, S. nimbus, is known from Pico da Neblina ("Neblina Peak"), in Amazonas state, which is located ca. 1,600 km west-northwest of Caxiuanã Forest. The Amazon is the most biodiverse biome in the world, but its invertebrates, and molluscs in particular, are still poorly understood (MiTTERMEIER et al. 2003, LIMA et al. 2021). Only about $15 \%$ of the land snail species known to occur in Brazil have been recorded from the Amazon (SALVADOR 2019).

Given the undersampling of the Amazon and its gargantuan area, it is to be expected that many species are yet to come to light. It is thus not surprising that some of those new species are already part of museum collections, just waiting to be studied. The specimen studied here was collected in 1998 and is an example of the long shelf-life invertebrates may have in museum collections before they are identi- fied and formally described. It is also a reminder of the importance of those collections for biodiversity studies (ALLMON 1994).

Unfortunately, Brazilian environmental policies have taken a turn for the worse during the catastrophic current administration (e.g. TOLLEFSON 2019). Thus, in all likelihood many new invertebrate species are being lost in the Amazon before being recognised and described, in a similar manner to what has been observed in other tropical areas (e.g. RICHLING \& BOUCHET 2013, SIMONE \& SALVADOR 2016).

\section{ACKNOWLEDGEMENTS}

I am extremely grateful to PAUL CALLOMON (ANSP) for providing access to and information about the specimen under his care; to JEAN-CLAUDE STAHL (NMNZ) for the photos of the new species; and to the two anonymous reviewers for their helpful feedback and suggestions.

\section{REFERENCES}

ALLMON W. D. 1994. The value of natural history collections. Curator 37: 83-89. https://doi.org/10.1111/j.2151-6952.1994.tb01011.x

BECK H. 1837. Index molluscorum præsentis ævi musei principis augustissimi Christiani Frederici. Hafniæ. https://doi.org/10.5962/bhl.title.77331

Birckolz C. J., Salvador R. B., Cavallari D. C., Simone L. R. L. 2016. Illustrated checklist of newly described (2006-2016) land and freshwater Gastropoda from Brazil. Archiv für Molluskenkunde 145: 133-150. https://doi.org/10.1127/arch.moll/145/133-150
BURROW E. I. 1815. Elements of conchology, according to the Linnæan system, illustrated by 28 plates, drawn from nature. R. \& A. Taylor, London.

https://doi.org/10.5962/bhl.title.11498

Calcutt J., Cuezzo M. G., Jackson M., Salvador R. B. 2020. Phylogenetic relationships and classification of Solaropsidae (Gastropoda: Stylommatophora). Archiv für Molluskenkunde 149: 181-193. https://doi.org/10.1127/arch.moll/149/181-193

Dinapoli A., Klussmann-Kolb A. 2010. The long way to diversity - phylogeny and evolution of the 
Heterobranchia (Mollusca: Gastropoda). Molecular Phylogenetics and Evolution 55: 60-76.

https://doi.org/10.1016/j.ympev.2009.09.019

DOHRN H. 1882. Beiträge zur Kenntnis der südamerikanischen Landconchylien. Jahrbücher der Deutschen Malakozoologischen Gesellschaft 9: 97-115.

EDGAR R. C. 2004. MUSCLE: multiple sequence alignment with high accuracy and high throughput. Nucleic Acids Research 32: 1792-1797. https://doi.org/10.1093/nar/gkh340

FÉRUSSAC A. E. J. P. J. F. D’AUdEBARD DE 1821. Tableaux systématiques des animaux mollusques classés en familles naturelles, dans lesquels on a établi la concordance de tous les systèmes; suivis d'un prodrome général pour tous les mollusques terrestres ou fluviatiles, vivants ou fossiles. Prodrome Limaçons (part 3.): 57-76 [Quarto ed.] vs. 49-72 [Folio ed.]. BertrandSowerby, Paris, Londres.

Folmer O., Black M., HoeH W., Lutz R., VRIJENHOEK R. 1994. DNA primers for amplification of mitochondrial cytochrome $\mathrm{c}$ oxidase subunit I from diverse metazoan invertebrates. Molecular Marine Biology and Biotechnology 3: 294-299.

Fontaine B., PERRARD A., BOUCHET P. 2012. 21 years of shelf life between discovery and description of new species. Current Biology 22: R943-R944. https://doi.org/10.1016/j.cub.2012.10.029

GMELIN J. F. 1791. Vermes. In: GMELIN J. F. (ed.). Caroli a Linnaei systema naturae per regna tria naturae, Ed. 13 Tome 1(6). G. E. Beer, Lipsiae. pp. 3021-3910.

GREEN S. V. 1998. The taxonomic impediment in orthopteran research and conservation. Journal of Insect Conservation 2: 151-159.

https://doi.org/10.1023/A:1009633811789

IHERING H. F. A. von 1905. O rio Juruá. Revista do Museu Paulista 6: 385-460.

KEMP C. 2015. Museums: The endangered dead. Nature 518: 292-294

https://doi.org/10.1038/518292a

LighTFOOT J. 1786. A Catalogue of the Portland Museum, lately the property of the Dutchess Dowager of Portland, deceased; which will be sold by auction by Mr. Skinner \& Co. London.

Lima M. S., Silva F. S., Simone L. R. L., SAlvador R. B., GUILHERME E. 2021. Terrestrial gastropods of Reserva Florestal Humaitá, southwestern Brazilian Amazon. Check List 17: 269-281. https://doi.org/10.15560/17.1.269

LINNAEUS C. 1758. Systema naturæ per regna tria naturæ, secundum classes, ordines, genera, species, cum characteribus, differentiis, synonymis, locis. Editio decima, reformata. Tomus I. Salvius, Holmiæ. https://doi.org/10.5962/bhl.title.542

LisBOA P. L. B. 1997. A estação científica Ferreira Penna/ ECFPn. In: LisBOA P. L. B. (ed.). Caxiuanã. Museu Paraense Emílio Goeldi, Belém, pp. 23-49.

Mittermeier R. A., Mittermeier C. G., Brooks T. M., PilgRim J. D., KONSTANT W. R., FonseCA G. A., KoRMOS C. 2003. Wilderness and biodiversity con- servation. Proceedings of the National Academy of Sciences 100: 10309-10313.

https://doi.org/10.1073/pnas.1732458100

MÜLLER O. F. 1774. Vermium terrestrium et fluviatilium, seu animalium infusiorium, helminthicorum, et testaceorum, non marinorum, succincta historia. Vol. II. Heineck \& Faber, Havniae et Lipsiae. https://doi.org/10.5962/bhl.title.46299

NORDSIECK H. 1986. The system of the Stylommatophora (Gastropoda), with special regard to the systematic position of the Clausiliidae, II. Importance of the shell and distribution. Archiv für Molluskenkunde 117: 93-116.

D'ORBIGNY A. 1835. Synopsis terrestrium et fluviatilium molluscorum, in suo per Americam meridionalem itinere collectorum. Magasin de Zoologie 5: 1-44.

PFEIFFER L. 1846. Symbolae ad historiam Heliceorum. Sectio tertia. Th. Fischer, Cassellis.

PFEIFFER L. 1850. Descriptions of twenty-four new species of Helicea, from the collection of H. Cuming, Esq. Proceedings of the Zoological Society of London. 17 (197-198) [“1849”]: 126-131.

PILSBRY H. A. 1893-1895. Manual of conchology, structural and systematic, with illustrations of the species. Ser. 2, Pulmonata. Vol. 9: Helicidae, Vol. 7, Guide to the study of Helices. pp. 1-225, pls 1-61. Philadelphia, published by the Conchological Section, Academy of Natural Sciences. [pp. 1-48, pls 1-14, 16 Nov 1893; pp. 49-112, pls 15-28, 19 Mar 1894; pp. 113-160, pls 29-40, 27 Jul 1894; pp. 161-366, pls 41-71, i-xlviii, 2 Feb 1895; index 1-126, April 1895].

RICHLING I., BOUCHET P. 2013. Extinct even before scientific recognition: a remarkable radiation of helicinid snails (Helicinidae) on the Gambier Islands, French Polynesia. Biodiversity and Conservation 22: 2433-2468. https://doi.org/10.1007/s10531-013-0496-2

RONQUiST F., TESLENKO M., VAN DER MARK P., AYRES D. L., DARLING A., HÖHNA S., LARGET B., LIU L., SUCHARD M. A., HuelsenBECK J. P. 2012. MrBayes 3.2: efficient Bayesian phylogenetic inference and model choice across a large model space. Systematic Biology 61: 539-542. https://doi.org/10.1093/sysbio/sys029

SALVADOR R. B. 2019. Land snail diversity in Brazil. Strombus 25: 10-20.

SAlvador R. B., CAVAllaRi D. C. 2014. A new species of Leiostracus (Gastropoda, Pulmonata, Orthalicoidea) from Espírito Santo, Brazil. Iheringia, Série Zoologia 104: 364-366. https://doi.org/10.1590/1678-476620141043364366

SAlvador R. B., CAVAllari D. C., SimONE L. R. L. 2015. Taxonomical study on a sample of land snails from southeastern Tocantins state, Brazil, with description of a new species. Journal of Conchology 42: 67-78.

Salvador R. B., Silva F. S., Cavallari D. C., Simone L. R. L. 2021. Terrestrial Gastropoda from the caves of Presidente Olegário, southeastern Brazil. Biota Neotropica 21: e20201169. https://doi.org/10.1590/1676-0611-BN-2020-1169

Sei M., Robinson D. G., Geneva A. J., Rosenberg G. 2017. Doubled helix: Sagdoidea is the overlooked 
sister group of Helicoidea (Mollusca: Gastropoda: Pulmonata). Biological Journal of the Linnean Society 122: 697-728. https://doi.org/10.1093/biolinnean/blx082

SHUTTLEWORTH R. J. 1854. Beiträge zur näheren Kenntniss der Land- und Süsswasser-Mollusken der Insel Portorico. Mittheilungen der Naturforschenden Gesellschaft in Bern 1854 (314-316): 33-56.

Simon C., Frati F., BeCKenbach A., CRespi B., LiU H., FLOOK P. 1994. Evolution, weighting, and phylogenetic utility of mitochondrial gene sequences and compilation of Conserved Polymerase Chain Reaction primers. Annals of the Entomological Society of America 87: 651-701. https://doi.org/10.1093/aesa/87.6.651

SimONE L. R. L. 2010. A new genus and species of camaenid from the Amazon Rainforest, Brazil (Pulmonata, Helicoidea). Journal of Conchology 40: 149-161.

Simone L. R. L., SAlvadoR R. B. 2016. Taxonomical study on a sample of land snails from Nanuque (Minas Gerais, Brazil), with descriptions of three new species. Stuttgarter Beiträge zur Naturkunde A, Neue Serie 9: 9-30. https://doi.org/10.18476/sbna.v9.a2

TAlaVera G., CASTREsana J. 2007. Improvement of phylogenies after removing divergent and ambiguous- ly aligned blocks from protein sequence alignments. Systematic Biology 56: 564-577.

https://doi.org/10.1080/10635150701472164

TOLLEFSON J. 2019. 'Tropical Trump' sparks unprecedented crisis for Brazilian science. Nature 572: 161-162. https://doi.org/10.1038/d41586-019-02353-6

WADE C. M., MORDAN P. B. 2000. Evolution within the gastropod molluscs: using the ribosomal RNA gene cluster as an indicator of phylogenetic relationships. Journal of Molluscan Studies 66: 565-570. https://doi.org/10.1093/mollus/66.4.565

WADE C. M., MordAN P. B., NAGGS F. 2006. Evolutionary relationships among the Pulmonate land snails and slugs (Pulmonata, Stylommatophora). Biological Journal of the Linnean Society 87: 593-610. https://doi.org/10.1111/j.1095-8312.2006.00596.x

WAGNER J. A. 1827. Testacea fluviatilia quae in itinere per Brasiliam annis MDCCCXVII-MDCCCXX [18171820] jussu et auspiciis Maximiliani Josephi I. Bavariae Regis augustissimi suscepto, collegit et pingenda curavit Dr. J. B. de Spix (...), digessit, descripsit et observationibus illustravit Dr. J. A. Wagner. C. Wolf, Munich.

Received: June 6th, 2021

Revised: June 27th, 2021

Accepted: July 7th, 2021

Published on-line: August 20th, 2021 